\title{
БЛАКИТНІ ВІДБЛИСКИ, БЛАКИТНІ ПЕРЕДЧУТТЯ. ЗАМІСТЬ ПЕРЕДМОВИ
}

DOI: $10.19195 / 0860-116 X .37 .2$

„Боже! Хто Тебе не чув в України/Блакитних полях, де так сумно душі (...)”1. Поля не бувають блакитними, але, однак, віримо Словацькому на слово, що в Україні стан речей виглядає інакше - що земля має, або принаймні буває там кольору неба, саме тому власне блакитний, бо всякий горизонт буває час від часу знівельований, і ми залишаємося сам на сам з тим усім, що $є$ в нас інше - „надприродне, понадчасове, нереальне”. Україна дає полякам можливість зрозуміти, що польська символічна фантазія - фантазматична підсвідомість духу - $є$ неминуче занурена в таємничий світ Сходу, і що не тільки сарматизм, але навіть польський романтизм - це просто варіанти „латинського орієнталізму”, потужні прояви дрімаючої в нас геокультурної суперечності. Важко собі уявити - зрештою і слухати стидно - що поступи міщанської ментальності врешті-решт замінять нас на голландців Сходу або чехів Півночі. Інша Річ Посполита неможлива, тому що маємо в підсвідомості образ нереальних, містичних, блакитних полів України. „Моральний труп кресівського шляхтича”, про котрого писав Павло Ясениця в спірній рецензії Дороги в нікуди, вживається в нас щораз глибше, але - згідно з археологічною надприродою психіки, яку відкрив і відтворив Фрейд - ніколи не зникне, таємно репродукуючи вічну частковість нашої західної орієнтації.

Після Другої світової війни славнозвісним олівцем Сталіна Польща була відсунута на Захід. Не відомо, чи сталося те, що мало статися (як вважав, наприклад, Сжи Стемповський), чи навпаки - була надламана основна вісь польської душі, а сама вона скотилася в прірву. Юзеф Віттлін розпачливо визнавав: „Не можу відмовитися від Львова, бо Львів не може відмовитися від

\footnotetext{
1 J. Słowacki, Dzieła, red. J. Krzyżanowski, t. 3, Poematy. Beniowski, Wrocław 1959, c. 116.
} 
фундаментальних складових моєї психіки. А цього жодні „концепти” політиків не змінять" 2 . Шістдесят років польської історії було вилучено на майже півстоліття 3 польського суспільного життя, щоправда, за винятком еміграційного письменництва, а також - після 1956 - дозволеного історичного дискурсу, дещо звуженого, обмеженого літературного канону, а також якихось неконкретних в своєму висловлюванні і абсолютно нечисленних кіноекскурсів на Схід ${ }^{3}$. Упродовж усього радянського півстоліття щось невиразно жевріло в свідомості поляків, і аж вкінці, після 1989 року, виявилося, що щось в нас надломилося i, всупереч, наприклад, литовським сумнівам, проявився в польському суспільстві - як і в польській політиці - широкий та тривалий консенсус щодо безпідставності будь-яких територіальних вимог до держав „простору УЛБ”, тобто України, Литви і Білорусії. Велика війна за Креси - як констатував на початку серпня 1945 року поранений партизан Лупашки Леон Лех Бейнар, надалі - Павло Ясениця - була остаточно програна. Не тільки тому, що чверть віку тому в Польщі помер „дух пригоди”4, але з більш суттєвих причин. Сучасний західний націоналізм, прищеплений після 1863 року полякам, як і литовцям, а особливо українцям (а саме тим „п’ємонтським”, тобто галицьким), виявився смертоносним для Речі Посполитої як ідеї. Як сучасний, так і західний соціалізм, показавши анахронізм заснованої на цій ідеї конструкції суспільства, зробив свою справу. Щось в нас усіх, як вже було сказано, надломилося. Федеративна програма - щодо України конфедеративна - Пілсудського не знайшла підгрунтя ані в нас, ані в них. Демократична тенденція польської політики дев'ятнадцятого сторіччя (Погонь і Архангел поруч з Орлом на знаменах січневих повстанців) деградувала - незважаючи на літературно досконалі протести молодого Юзефа Мацкевича та інших - до сучасної фатальної форми політики меншин Другої Речі Посполитої.

Ідея польського політичного народу, надетнічного, заражена вірусом широкомасштабного модернізму, виявилася слабкою, а в схованому духовному житті поляків Польської Народної Республіки ця слабкість раптово стала очевидною. Найшвидше виявила це паризька „Культура”, і найвлучніше це було висвітлено власне пером Юліуша Мєрошевського, але, зрештою, не тільки ним. Повернення - а саме приїзд - Станіслава Ката-Мацкевича до нової Польщі 1956 року було безсумнівним і багатозначним символом політичного банкрутства багатовікового сентименту. Значна частина пізнішої історичної есеїстики тогочасного редактора віленського „Слова” - у своєму чудовому,

2 Згідно з: R. Habielski, Realizm, wizje i sny romantyków. O pisarstwie Juliusza Mieroszewskiego, [w:] J. Mieroszewski, Finat klasycznej Europy, oprac. R. Habielski, Lublin 1997, c. 48.

3 В вигляді екранізації другої і третьої частини “Трилогії” Сенкевича і екранізаціях менш відомих творів, таких як "Мати Іоанна від ангелів”, “Локіс" чи “Знахар”.

4 Так говорив Міхал К. Павліковський, коментуючи дещо капітулянтське - у стосунку до федеративних планів Пілсудського (а тим більше замірів Петлюри) - Ризьке Перемир'я. 
в шекспірівському дусі поєднанні трагічних і комічних наголосів - стає виразом боротьби в цій справжній польській свідомості вражаючого почуття і холодної прагматики, польського раціоналізму і литовської метафізики. Що далі з Польщею? Що далі з Україною та Литвою? „Але сьогодні вже надто пізно, щоб відновлювати ці суперечки"5. Чи насправді так?

Після Помаранчевої революції, а особливо подій на Майдані, здається (хоча важко висловити це конкретно), що вже запізно, але разом $з$ тим - можливо, можливо - ще не прийшов на це час. А саме не прийшов час трактувати культурні структури і можливості у виключно історичних категоріях, що склалися на широкому просторі Першої Речі Посполитої, на основі, так би мовити, gloria victis. Немає, звичайно, повернення до простих імперських фантазій, не треба посилатися на Бовуа, щоб знати, або щонайменше передчувати, що часи польської домінанти в Україні, спочатку політичної, а потім економічної і загально цивілізаційної, не обмежуються тільки, особливо з перспективи самих українців, багатонаціональною ідилією. Ця модель зовсім застаріла. Однак геополітична вісь Гданськ - Одеса та їі менші геокультурні різновиди Варшава - Київ, Краків - Львів спокушають можливостями розширення діапазону і характеру модернізаційних метаморфоз Східної Свропи. При цьому здається, що і українська держава, і польська могли б цим у великій мірі скористатися. Так само, як і обидві культури. Спільна перспектива, яка постає перед нами, з багатьох причин залишається віддаленою та абстрактною, проте не можемо не відчувати іiї блакитної привабливості. Вальтер Гропіус, засновник знаменитого Баухауса, зауважує, що „проектування великого будинку відрізняється від винаходу простого стільця виключно рівнем прогресу, а не фундаментальними принципами" 6 . Всупереч тому, що могло б здаватися, абстрактна перспектива українсько-польського зближення, про яке пишу вище, не має виключно або передусім політичного характеру. На відміну від В. В'ятровича - автор настільки відомої в Польщі, наскільки контроверсійної „Другої польсько-української війни 1942-1947" - не визнаю порозуміння без поєднання як достатнього фундаменту нашого сусідства, незважаючи на те, що історія нашої частини світу від якихось двох років серйозно пришвидшилась, і таке порозуміння остаточно може виявитися більш терміновим, ніж поєднання, так що можна буде повторити за Яном Кеневічем: „Або відкриємо новий розділ в історії, в котрому знайдемо деякі знайомі нам варіанти, або будемо чекати на повторення історичних calamitates" 8 .

5 S. Cat-Mackiewicz, Pisma wybrane, oprac. J. Sadkiewicz, t. 8, Herezje i prawdy, Kraków 2012, c. 198.

6 W. Gropius, Petnia architektury, przeł. K. Kopczyńska, Kraków 2014, c. 39-40.

7 W. Wjatrowycz, Porozumienie bez pojednania, rozmawia M. Wojnar, „Nowa Europa Wschodnia" 2016, nr 1, c. 128.

8 J. Kieniewicz, Spotkania Wschodu, Gdańsk 1999, c. 237. 
Давайте почнемо, однак, від проектування „стільця Гропіуса”, концептуального прототипу можливої будови східноєвропейського майбутнього. На початку цього ескізу я реконструював у трьох словах присутній в польській колективній свідомості та несвідомості „український сентимент”. Проте, я свідомо відмовився від реконструкції - мабуть сильнішої, коли йдеться про суспільний діапазон - „українського ресентименту”, що не означає, що я вважаю питання такої реконструкції річчю тривіальною чи, тим більше, шкідливою. Навпаки. На фільм Войцеха Смажовського про Волинь чекаю $з$ деякою тривогою, але також з надією, що сила кінематографу дозволить перенести дискусію про польсько-українське сусідство в найширший форум, який об'єднує - у видимий і невидимий спосіб - не десятки людей, але тисячі, щонайменше тисячі. 3 аналогічною надією i, звичайно, 3 такою ж тривогою я 6 чекав на український кінематографічний портрет польського двору чи акції „Вісла”, не згадуючи вже про події сімнадцятого століття. Не тому, що я хотів би викинути зі свідомості блакитні поля, а заради того, щоб їх власне там залишити. „Границі Свропи як концепту або ідеї встановлюють пануючі чи правлячі, проте, просторовий вимір європейської цивілізації ми носимо в собі. Простори, які цінуємо, змінюються повільніше від політично визначених, та вони явно пов'язані з рішеннями людей"9.

\section{Павло Кулітовський 3 польського переклала Мариана Бетса}

9 J. Kieniewicz, Ekspansja, kolonializm, cywilizacja, Warszawa 2008, c. 267. 